\section{Twenty Years On: Looking at Gender Equality}

\section{GERALDINE MCDONALD}

\section{Abstract:}

A conference in 1995 provided the opportunity to find out what had happened to equality for women and girls in education over the twenty years since International Women's Year, the report of the Select Committee on Women's Rights, and the landmark conference on Education and the Equality of the Sexes. This chapter compares the issues for women in 1975 with those of 1995, assesses the gains and the losses, and notes changes in the way in which Maori and non-Maori women have viewed the issues.

s gender equality in education still an issue ${ }^{1}$ This question was the focus of a conference, Education and the Equality of the Sexes: Twenty Years On, held in July 1995 at the School of Education, The University of Waikato, on the initiative of Noeline Alcorn (Alcorn, 1995). ${ }^{2}$ The conference took stock of what had happened since an earlier conference, Education and the Equality of the Sexes, held in November 1975 (Department of Education, 1976) as part of the activities of International Women's Year (IWY). This was first of three governmentsponsored conferences. The education conference was jointly sponsored by the Committee on Women and the Department of Education. Both are now past history. Five of the women listed as present at the original conference were present also at the 1995 conference. ${ }^{3}$ The other 1995 participants included many who have worked for gender equality in the intervening years.

I will look at the concerns of the 1975 conference to see whether these are still viewed as concerns, either by the speakers at the 1995 conference, or in work published or papers given during the year under review. The report of the 1995 proceedings contains contributions from 11 women. References to the papers given at the conference will be by the surname of the speaker and page reference in the corresponding report. Other papers and publications will be referred to by date in the usual manner.

\section{Background to the 1975 Conference}

On 13 September 1973, Parliament appointed a Select Committee of seven members to receive submissions and evidence of the extent of discrimination against women in New Zealand. The committee considered women at home and women outside the home, earnings and employment opportunities, legal and commercial transactions, women in public life, how to implement equal rights, childcare, and education and training. The committee met over nearly two years and its report The Role of Women in New Zealand Society was published in June 1975 and launched at the Second United Women's Convention held in Wellington. The committee concluded that

... most aspects of discrimination ... continue to be the subject of inaction and the committee accepts without reservation the need for an accelerated effort to remove all impediments to the equal participation of women in society. (Select Committee on Women's Rights, 1975)

I well remember the feeling of excitement that many of us felt upon reading the report. Here was a platform for action. Here was official sanction for matters which had previously been dismissed as on the wilder shores of women's liberation. Today the report would be recognised as moving women's issues from the margin to the centre. However, the report did not mention Maori women and their concerns.

Amongst the findings were that girls were leaving school earlier than boys, that girls were not taking mathematics, chemistry and physics in the same proportions as were boys. Women represented over a third of total enrolments at university but the majority of girls were taking an arts degree. The more advanced the degree the smaller the proportion of women enrolled.

The committee recommended that outmoded views of male and female roles be counteracted by the removal of sex-stereotyping in infant readers. Vocational guidance was to be strengthened in secondary schools, and boys and girls were to follow the same manual training curriculum. Childcare was given a special section in the report, and amongst the recommendations was that the responsibility for preschool childcare ultimately be vested in the Department of Education. The Select Committee's themes and issues, apart from those to do with women at university, were all addressed in the 1975 education 
conference. While the Select Committee's report gave official sanction to women's issues, the 1975 conference engendered the enthusiasm, commitment and understanding required to support lengthy campaigns for action.

\section{The 1975 Education Conference}

Rosslyn Noonan was the National Organiser for International Women's Year. She was also a member of the planning committee for the 1975 conference. Twenty years later she summed up the achievements of the second conference in the following way:

For the first time it allowed feminist women to effectively engage with key decision makers in education. Secondly, it provided sufficient resources to support a comprehensive review of issues affecting the education of women and girls, enabling the identification of and agreement on key priorities for action. No conference since has matched its achievements. Nor has any been as creative and challenging in its methods. (Noonan, p. 34)

The conference report is a publication of 72 pages, with photographs of the participants by Ans Westra. It contains summaries of pre-conference research projects, a detailed description of consciousness-raising activities, reports of group discussions, and recommendations for action addressed to a range of agencies. It provides estimates of the costs of the recommendations made and gives a date for their achievement. The report expressed the feelings as well as the conclusions of the invited participants. It is now a collectors' item.

The 1975 conference was the first time that women from early childhood, primary, secondary, vocational and continuing education had had such an opportunity to get together and to focus on issues affecting women and girls. Not all the individuals taking part were committed to women's causes or saw themselves as feminists. Some of the women present had forged careers in education and were placed at risk by the recommendations and proposals for change which emerged. Nevertheless the conference expressed an energy, unity and determination across a broad front. Because the Department of Education did not control the universities there was no group discussing the needs of university women; either students or staff. Lesbian women contributed substantially to the conference, but official recognition of gay women was probably too much to expect of a governmentsponsored conference in 1975 . The 1995 conference on the other hand strongly supported freedom from harassment or discrimination on the grounds of gender or sexuality.

In 1975, equal numbers of men and women were invited. However, many of the men invited to the conference on education found that they were too busy to attend, and the final count was about one-third men. Many of the men present found, as the conference proceeded, that they had pressing engagements elsewhere, or that their health had failed them. They were uncomfortable in groups in which women made recommendations, and they found that their standard answer to any proposals for change, "You can't do that", no longer worked. The women were determined to be heard. Maybe some men found that they could not stand women appearing to bite the hand that fed them. This was in the time of the welfare state, of course, and many of the officials present were accustomed to thinking that improvements for women were by their grace and favour. The most fundamental reason for dropout from the conference, however, was probably that women had carried out research, written papers and for once they were insiders with secure knowledge. The men were the outsiders. Women understood that men held the power and would hang on to it at any cost and this is what they challenged. At the 1995 conference all the participants were women.

In 1975, Maori women made it clear that they did not support gender equality as it was being promoted by European women. It is significant that at the earlier conference there were few Maori women, and that their concerns were combined in a section of the report called "Maori and Pacific Islands women". Mere Penfold, Vice President of the Maori Women's Welfare League, which had carried out pioneering work in early childhood education, was the reporter.

Since that time, the conceptualisation of the role of Maori women in education, and what are seen as Maori issues, have both evolved dramatically, and in a manner quite distinct from that of other ethnic groups. The whole issue of "difference" between Maori and European experience, and between Maori men and Maori women, came through clearly at the 1995 conference, whereas it was absent from the earlier one. A recent publication (Johnson \& Pihama, 1995) analyses this issue of "difference" and asks, particularly, what differences count for Maori women.

At the 1995 conference, Elizabeth McKinley reported on Maori women's access to tertiary education. Maori women are now the fastest growing group in tertiary education, and there are more of them in tertiary education than there are Maori men (McKinley, p. 83). But they are still under-represented in post-graduate courses, and because many 
are mature students they are ineligible for "study right" grants, and likely to be paying more for their education. Many are upgrading their qualifications while holding down fulltime jobs and raising families. Rita Walker, who also spoke at the 1995 conference, confirmed the pressures that this brings about. McKinley said "One of my biggest concerns is that Maori women are under-represented in relation to both Maori men and European groups, in areas critical to Maori economic development" (p. 84).

Over the past 20 years Pacific Islands women have established their own place in education, especially in the field of early childhood. Diane Mara, one of the participants at the 1995 conference, has recorded their achievements and described the strategies they have used to make their distinctive voices heard (Mara, 1995).

\section{Structural Changes}

There are three sectors of education of concern to women, each of which has undergone major change since 1975. Early childhood has achieved a great deal; vocational education has been completely transformed; and many community education initiatives have suffered from lack of funds.

In the proceedings of the 1975 conference the early childhood group was described as an angry group. At the 1995 conference, Anne Meade went through the 1975 recommendations and showed how many of these had been put into effect over the last twenty years. Transfer of childcare from Social Welfare to the Department of Education, three year training for early childhood teachers, movement towards equitable funding, and increases in salary levels had all been achieved.

However, there has been an erosion of a number of the gains in recent years as monetarist economic policies have gained ascendancy. Too often the dollar has become more important than the well-being of women and children. (Meade, p. 32)

Linda Sissons (p. 54) referred "to the total change in the landscape of vocational education." In 1995 she focussed on "phenomena that did not exist at all twenty years ago; the National Qualifications Framework and the Industry Training Act and the Skill New Zealand strategy". Although these reforms were not introduced to achieve equality for women, Sissons pointed out there were advantages for women now that small chunks of credit can be built into qualifications. She also referred to some potential hazards. The close interdependence of industry and education in the new vocational training climate has the potential for adding the inequalities women experience in one sphere to inequalities in the other.
Industry Training Organisations are set up under the Industry Training Act. These ITOs have the task of setting the skills standards for their industry or profession. "The thirteen industries in which the largest numbers of female employees are found are covered by just 25 percent of the ITOs currently registered" (Sissons, p. 57).

The reporter for the continuing education working group at the 1975 conference was Beverley Morris. Continuing education was then seen as a site of particular importance to the achievement of equality for women, and the working group argued for an adequate level of resourcing. Continuing education was provided by a number of agencies, many of them community based. In many, women played an important role. Over the years this sector of education has suffered funding cuts and competition from other providers. A case study of the New Zealand Association for Community and Continuing Education (NZACCE) illustrates what the voluntary sector of continuing education has experienced (Stewart, 1995).

\section{Management and Senior Positions}

Campaigns for better pay and conditions for women teachers go back at least to the turn of the century (McCardle,1993). The topic of how to get women into senior management was pursued at the 1975 conference by all the sectors of education represented there.

Twenty years ago, whenever women teachers raised the topic of equality in employment, they received two stock responses; "Women do not apply for senior jobs" or, "Women do not like administration". Lenore Webster, one of the convenors for the secondary group at the 1975 conference, carried out a small study which found some quite surprising things about the promotion prospects of women teachers in secondary schools. These are summarised in the report of the 1975 conference (pp. 25-26)

Early childhood groups asked for the establishment of a position of Director of Early Childhood Education. Women pursued this goal over several years, succeeded in getting such a position, and then found that the first person to be appointed was a man.

As a direct consequence of the 1975 conference, the Department of Education resourced a Teacher Career and Promotion study (Department of Education, 1982). The Department (more recently the Ministry) of Education continued to publish statistics on the position of women teachers (see e.g., Slyfield, 1993). Judy Whitcombe brought the picture up-to-date for the 1995 conference (Whitcombe, pp. 72-82). She reported that while there have been gains in women's access to senior positions 
in education, in view of the increasing proportion of women in teaching, the number of women principals is not as spectacular as might have been expected.

A Non-Governmental Organisations Forum, consisting of displays and workshops, accompanied the UN Fourth World Conference for Women held in Beijing in 1995. One of the topics for this display was women's access to management positions in education. ${ }^{4}$ In 1995 Anne Dickinson was appointed as the head of St Patrick's College in Wellington and so became "the first woman to head a Catholic boys' secondary school in New Zealand." ${ }^{2}$

Margaret Wilson made the first national study of the position of academic women in New Zealand universities (Wilson, 1986). For the 1995 conference she provided preliminary findings from a follow-up study. She found that over the ten-year period there had been a 2 percent increase in the number of women in senior academic positions; the increase had been approximately 10 percent at the senior lecturer and lecturer level and, at the bottom of the academic hierarchy women had increased by 22 percent. Wilson comments, "This rate of increase is disheartening for those women who work within the university system, and should act as a warning to women who are considering an academic career" (Wilson, p. 65). Under these circumstances, it is important to note that in 1995 Anne Smith was appointed Professor and Director of the Children's Issues Centre at Otago University, and Helen May took up the position of Professor of Early Childhood Teacher Education, funded jointly by Victoria University of Wellington and the Wellington College of Education.

The issue of women and management is still under investigation. How can women be helped to reach the top positions (Strachan, 1995)? Do women begin their careers with the thought of aiming at senior positions (Williams, 1995)? How do women in management behave and how is their behaviour interpreted by others (Court, 1995)? What is the effect of marriage on careers (Cooke, 1995)?

The NZEI has kept women's issues alive (NZEI, 1985), has supported a hui for Maori women (NZEI, 1992) and has conducted a vigorous programme to encourage women to apply for senior positions in primary schools (NZEI, 1991).

\section{Power and Influence}

For the 1975 conference, Geraldine McDonald analysed the gender composition of some of the more influential of the bodies set up to give advice on education to government, and concluded that no matter how many persons there were in the group the rule appeared to be, "Let's get a couple of women along", neither of whom would be in the chair.

Over the last twenty years determined efforts have been made to get women on to advisory committees, selection panels for senior appointments in the education service, boards, commissions and tribunals. A Women's Appointment File was established and maintained by volunteers until it was taken over by the Ministry of Women's Affairs. As the years went by it did appear that women had gained representation on a wide range of consultative and advisory bodies in education. Moreover, women were appointed to top educational positions within the Public Service. This relatively sudden access of women to positions of power was due in no small measure to a group of women Cabinet members and members of parliament in the Fourth Labour government who were committed to equality (Wilson, p. 94). Since then the government has changed, and women have virtually disappeared from Cabinet. At present there are two Associate Ministers of Education. Why are neither of these positions filled by a woman?

Today there are many consultative groups. In some cases the Ministry of Education has established a group and the Minister has a parallel reference group. Noeline Alcorn examined the composition of the Tertiary Management Reform Group (13 persons of whom 2 are women), the Ministry Tertiary Lead Group ( 10 persons of whom 1 is a woman), and the Schools Consultative Committee (11 persons of whom 3 are women). Furthermore there are organisations such as the Business Roundtable and the Education Forum offering advice on education. Their preferred technique is to bring in an overseas "expert" and this person will be steered around informants, amongst whom one is likely to find the obligatory two women.

\section{Research on Inequality}

By the time of the 1975 conference, the Society for Research on Women (SROW) had demonstrated the usefulness of research as a means of fighting inequality. SROW had also trained many women volunteers to manage its research projects. By 1975 there were some women employed as researchers in education. Yet in 1978 there was a Ministerial Conference on Educational Research (Department of Education, 1979) at which five major papers were given, all by men, and all reported in full. These covered the history, organisation and financing of educational research, the training of research workers, and research methodology. Two women had prepared shorter discussion papers, and these were summarised in the report. Only one of the latter 
was on a topic related to women's interests. In general, the women's contributions were seen as representing those who were consumers constituting a "market" for educational research.

The Ministerial Conference resolved to explore the establishment of a New Zealand association for educational research. The experience of similar associations in other countries such as Australia suggested to the women on the planning committee for the first conference of what came to be called the New Zealand Association for Research in Education (NZARE) that deliberate effort was needed to include women. The committee commissioned state of the art papers on a wide range of topics including women and education, child development and early childhood education (NZARE/Delta, 1980). NZARE has always given women an opportunity to report their research to the wider community and to share in the conduct of the organisation. Women have now moved into educational research in substantial numbers both as a consequence of taking courses for higher degrees and as a career.

While not all women researchers have chosen to investigate topics of special concern to women, substantial numbers have done so. They can be found working or studying in universities, colleges of education and polytechnics, as well as carrying out studies on their own account. Educational topics have also been represented in the conferences of the Women's Studies Association, established in 1976, and feminist analyses of educational topics have been published in the Women's Studies Journal founded in 1984 with Margot Roth as editor.

\section{Challenging Explanation and Action}

Strategies for action are dependent upon accurate explanation of the causes of inequality. In 1975 we thought we knew the answers. Now simple explanations are seen to be insufficient.

There is scepticism about the efficacy of teachers as role models in improving the position of women. Karen Sewell, principal of a coeducational secondary school, told the 1995 conference:

Strangely adolescents don't want to be like me. They model

themselves on people in Baywatch, and they admire bands which I

can't even bear to listen to. (Sewell, p. 44)

Sewell makes the important point that equality is not achieved through the passive concept of role-modelling, but depends upon active strategies of support for women. For example, "a mentor makes a trapdoor and helps [women] through" the glass ceiling. Sewell also examined the concept of self-esteem which has loomed so large in educational thinking about girls and ethnic groups alike. Sewell said that self-esteem follows, rather than precedes, achievement.

The best way of building self-esteem is to organise successful learning experiences so that the learner has something to feel confident about. (Sewell, p. 48)

The intellectual movement referred to generally as post-modernism has also made a difference to the way in which women interpret their position in the world. Considerable attention has been paid to the discourses which construct limited spaces for women and set boundaries for what it is possible for women to achieve. There has been a lively discussion surrounding girls and women and science. Arguments have been based on a deconstruction of the concept of science (McComish, 1995), evidence that practical interventions can work (Kirkwood, 1995), and the argument that the "problem" lies neither with science nor with girls, and that to persist with the kind of discourse of difference embedded in official documents from the Ministry of Education leads to policies asking for different forms of science education for an increasing number of different population groups (Gilbert, 1995).

Jones and Jacka (1995) have shown how in policy documents girls are consistently assumed to be not achieving as well as boys. There is, as the authors point out, no truth in this assumption. The myth is enshrined in the report of the 1975 Select Committee on Women's Rights. On one page we read that female university students are "particularly successful" (p. 46) and two pages later that the committee believed that social factors explained "women's lesser educational achievements" (p. 48). There was then, and continues to be, a confusion between progress through the education system and achievement at any given level of the system.

Women of the same age and same educational qualifications as men earn on average less income (McDonald, 1988). A Women's Education Coalition of Aotearoa paper prepared for the New Zealand delegation to the 1995 Beijing conference showed that at all qualification levels women fared worse than men in weekly wages.

Although sex-stereotyping was removed from infant readers, sexstereotyping is still alive and well in New Zealand classrooms and curriculum materials (Alton-Lee \& Densem, 1992).

The empowerment of women has assumed greater importance as time has gone by. This is especially the case for Maori women, who fill dual positions of powerlessness (Johnson \& Pihama, 1995). One strategy has been the development of liberating pedagogies to raise women's consciousness of their position and to critique their oppression. As a 
result of these and other strategies there is now a much greater recognition and understanding of what the issues are than was the case twenty years ago.

\section{Celebrating and Valuing}

Rosslyn Noonan called on women at the 1995 conference

... to acknowledge the influence and power we have gained. It is time to take responsibility for building. And that is a lot harder than clinging to the roles of victim and oppressed. (Noonan, p. 34)

In keeping with the aim of valuing women's work, Geraldine McDonald (McDonald, pp. 11-20) argued at the 1995 conference that literate societies are maintained by women as teachers and by women as mothers. Rose Pere in her keynote address celebrated Maori culture. She described the strength she gained from her Maori heritage, and how it provided her with strategies for dealing with the denigration experienced by Maori, both women and men (Pere, pp. 21-23). In recording the achievements of Maori women over the last 20 years, she affirmed her belief in positive discrimination for women, but also reported her belief that "sexism and racism are not similar ... racism is definitely worse" (Pere, p. 21).

Irwin \& Ramsden (1995) have recently published a collection of the writings of Maori women. Another notable publication is a history of Hukarere (Jenkins \& Matthews, 1995) described in the introduction by Linda Smith as "about a struggle by Maori women to be educated." The use of oral history (Middleton \& May, 1995) has been a method used by both Maori and European women, and it has also provided content for feminist pedagogy.

\section{What Lies Ahead?}

Margaret Wilson summarised the issues to be faced in the new social and political climate. There is no one source of authoritative decisionmaking, which means that policies relating to the equality of women and girls are dependent on agreement between a large number of people for their implementation.

... we see an increase in the number of sites of policy and political decision-making.... the public sector restructuring has contributed to this through the disestablishment of a centralised public service but the introduction of MMP has created a competitive market of sorts in political decision-making. (Wilson, pp. 92-93)
Wilson deplored the fact that women's scholarship and ideas are not reflected in public policy decision-making. She advised women to lobby politicians and bureaucrats, but added that they will need relevant information, and observed that the commercialisation and privatisation of information may make this difficult to obtain (see also, O'Neill, 1995). Wilson challenged the conference to keep working for the equality of women and girls.

\section{Conclusion}

There have been considerable gains in women's access to education. There are now more women than men in tertiary education. Both Maori and non-Maori women have moved into senior positions in schools, tertiary institutions and education agencies. There has been an explosion of research on the education of women and girls. There have been gains in all the areas over which women have control.

But gender equality remains an issue (Bird, Watson \& Leahy, 1995). We still need "an accelerated effort to remove all impediments to the equal participation of women in society" (Select Committee on Women's Rights, 1975). These impediments lie largely in the broader society rather than within education itself, and women will have to deal with a society which is very different in structure and functioning from the one we knew in 1975.

\section{Notes}

1. I have used the word "equality" because it reflects the terminology of twenty years ago and because discussions of equality and equity generally canvass the same issues.

2. The proceedings can be obtained from the School of Education, University of Waikato, P B 3105, Hamilton. The cost is $\$ 20.00$ plus postage.

3. Noeline Alcorn, Wendy Lee, Geraldine McDonald, Beverley Morris and Rosslyn Noonan. Dame Miriam Dell co-chaired the 1975 conference and although she could not attend the 1995 conference she supplied a message which was read there and is reproduced in the proceedings.

4. The panels have now had material from the Beijing conference added to them and will be touring New Zealand during 1996 as the "Beijing Display".

5. The Dominion, December 12, 1995, p. 3. 


\section{References}

Alcorn N. (Ed.) (1995). Proceedings of the Conference on Education and the Equality of the Sexes: Twenty Years On, 2-4 July. Hamilton: School of Education, The University of Waikato.

Alton-Lee, A. \& Densem, P. (1992). Towards a gender-inclusive school curriculum: Changing educational practice. In S. Middleton \& A. Jones, Women and education in Aotearoa 2. Wellington: Bridget Williams Books.

Bird, L., Watson, S. \& Leahy, H. (1995). Secondary education: Is gender still on the agenda. Conference on Education and the Equality of the Sexes: Twenty Years On, 2-4 July. Hamilton: School of Education, The University of Waikato.

Cooke, K. (1995). From marriage banns to marriage bans and beyond: The changing impact of marriage upon the teaching careers of women. Paper presented at the NZARE Conference, Massey University, 7-10 December.

Court, M. (1995). Good girls and naughty girls: Rewriting the scripts for women's anger. In B. Limerick \& B. Lingard (Eds.), Gender and changing educational management (pp. 150-161). Rydalmere: Hodder Education.

Department of Education. (1979). The Ministerial Conference on Educational Research 1978. New Zealand Journal of Educational Studies, 14 (Supplement).

Department of Education. (1982). Teacher career and promotion study. Wellington: Department of Education.

Department of Education. (1976). Education and the equality of the sexes: A report on the national conference in International Women's Year 1975. Wellington: Department of Education.

Gilbert, J. (1994). Beyond "Girls can do anything": The deconstruction and reconstruction of feminist approaches to science education in New Zealand. Paper presented at the annual conference of the Australian Association for Research in Education, Newcastle University, November.

Irwin, K. \& Ramsden, I. (Eds.). (1995). Toi wahine: The worlds of Maori women. (Illustrated by Robyn Kahukiwa). Auckland: Penguin Books.

Jenkins, K. \& Matthews K. M. (1995). Hukarere and the politics of Maori girls' schooling. Palmerston North: Hukarere Board of Trustees and The Dunmore Press.
Johnson, P. \& Pihama, L. (1995). What counts as difference and what differences count: Gender, race and the politics of difference. In K. Irwin \& I. Ramsden (Eds.). Toi wahine: The worlds of Maori women (pp. 75-86). Auckland: Penguin Books.

Jones, A. \& Jacka, S. (1995). Discourse of disadvantage: Girls' school achievement. New Zealand Journal of Educational Studies, 30(2), 165175.

Kirkwood, V. (1995). Response to "Gender issues and constructivism". Access, 13(2), 144-155.

McCardle, F. (1993). New Zealand Women Teachers' Association. In Anne Else (Ed.), Women Together (pp. 214-216). Wellington: Historical Branch Department of Internal Affairs \& Daphne Brasell Associates Press.

McComish, J. (1995). Gender issues and constructivism: Problems of theory. Access, 13(2), 129-143.

McDonald, G. (1988). The construction of inequality for women and Maori. Women's Studies Journal, 4(1), 5-18.

Mara, D. L. (1995). Te puai no te vahine: Pacific Islands women, education and power. Paper presented at the NZARE Conference, Massey University, 7-10 December.

Middleton, S. \& May, H. (1995). Towards an oral history of educational ideas in New Zealand as a resource for teacher education. Paper presented at the Annual Meeting of the American Educational Research Association, San Francisco, April 18-22.

New Zealand Association for Research in Education. (1980). Research in education in New Zealand: The state of the art. Delta Research Monograph 3. Palmerston North.

New Zealand Educational Institute. (1992). Report on Te Puawaitanga o te Wahine Maori Hui. Wellington: NZEI.

New Zealand Educational Institute. (1991). Don't cancel yourself out before you've run the race. 2 nd ed. Wellington: NZEI.

New Zealand Educational Institute. (1985). Report on the Decade for Women 1975-1985. NZEI Annual Report, 55-62.

O'Neill, A-M. (1995). New Zealand education and the movement to the Right: Implications for gender equity, policy and practice. Paper presented at the Annual Meeting of the American Educational Research Association, San Francisco, 18-22 April.

Select Committee on Women's Rights. (1975). The role of women in New Zealand society. Wellington: Government Printer.

Slyfield, H. (1993). The position of women in education 1991 and 1992. Wellington: Ministry of Education. 
Stewart, J. (1995). The New Zealand Association for Community and Continuing Education (NZACCE) 1982-1992: A case study of the influence of feminist perspectives on adult education, policy and practice. Paper presented at the NZARE Conference, Massey University 7-10 December.

Strachan, J. (1995). Making a difference: Changing the gender balance in educational leadership. Waikato Journal of Education, 1, 151-162.

Williams, R. (1995). Gender differences in the career-aspirations of students and beginning teachers. Paper presented at the NZARE Conference, Massey University, 7-10 December.

Wilson, M. A. (1986). Report on the status of academic women in New Zealand. Wellington: Association of University Teachers of New Zealand (Inc.).

\section{The author}

Geraldine McDonald is Honorary Fellow in the Faculty of Education, Victoria University of Wellington. Her first publication on gender appeared over thirty-five years ago and she has continued to write on issues of concern to women and girls. 